\title{
Patterns for Arsenate and Trace Element Relationships in Surface Water and Groundwater of Obuasi Municipality of Ghana
}

\author{
Alexander Kwaku Banson*, Richard Kwasi Amankwah, Samuel Agyarko Ndur \\ Dept. of Minerals Engineering, University of Mines and Technology, Tarkwa, Ghana \\ Email address: \\ alexkbanson@gmail.com (A. K. Banson), ramankwah@gmail.com (R.K. Amankwah), samndur@gmail.com (S.A. Ndur) \\ To cite this article: \\ Alexander Kwaku Banson, Richard Kwasi Amankwah, Samuel Agyarko Ndur. Patterns for Arsenate and Trace Element Relationships in \\ Surface Water and Groundwater of Obuasi Municipality of Ghana. International Journal of Environmental Protection and Policy. \\ Vol. 3, No. 5, 2015, pp. 169-180. doi: 10.11648/j.ijepp.20150305.17
}

\begin{abstract}
Obuasi Municipality is a historic gold mining tropical community that has a massive cocktail of old and active anthropogenic arsenic and trace metal storage structures and activities. Given the potential health impact of elevated arsenic and trace metals in surface and ground water of Obuasi Municipality, it is necessary to assess the distribution and possible link between arsenic and trace metals found in surface water and ground water of the study area. Arsenic is predominant as arsenate in the Obuasi Municipality. In response to this need, the study used statistical and geochemical analytical tools to identify patterns of relationships between arsenate distributions and trace metals in surface water and groundwater of the study area.
\end{abstract}

Keywords: Arsenic, Arsenate, Trace Metals, Obuasi, Ghana, Surface Water, Groundwater

\section{Introduction}

Obuasi Municipality is located in the western part of the main Ashanti-Prestea gold belt mineralization and lies in the southern part of Ashanti Region of Ghana. The study area has a long history of artisanal mining predating large scale mining. Artisanal mining was recorded in the area as early as $1471[1,2$, 3 , 9]. Currently, active artisanal mining is intense, but conducted by illegal miners, since almost the entire area is covered by the concession of Anglogold Ashanti Limited, Obuasi Mine [1,9]. Arsenic which is often associated with gold in the study area occurs predominantly as arsenopyrite and as a trace element in the pyrite, pyrrhotite, bournonite, tetrahedrite, sphalerite and aurostibnite [4, 9]. The gold particles are generally fine-grained but some are visible to the naked eye [4]. Gold sulfide ores occur as disseminated assemblage of arsenopyrite, pyrite, pyrrhotite with minor chalcopyrite, stibnite, sphalerite and galena in metasediments and metavolcanics in which carbonate and sericite are the prominent alteration minerals [4,5]. Important gangue minerals in the study area are quartz, carbonate, chlorite, and sericite, along with carbonaceous matter [4,5]. Generally, the finer arsenopyrite grains are found to contain high gold concentrations occurring as sub-microscopic gold particles, and supergene concentration of gold from the sulfides extends from depth of between $30 \mathrm{~m}$ to $80 \mathrm{~m}$ [2]. Ore deposits of the study area occur in a major shear zone with a proven lateral extent of $8 \mathrm{~km}$ and depth of $1600 \mathrm{~m}$ (Amanor and Gyapong, 1988). Figure 1 shows a geological map of the study area.

Previous mining operations in the Obuasi Municipality has left behind open mined out pits which are filled with water serving as habitat for fishes and other aquatic organisms. Liquid discharges at AGA from the past to present which are likely to contribute to release of arsenic and other trace metals into surface and ground water are effluent from the processing plants, seepages and discharges from tailings dams, run-off pits and exploration activities. AGA has operated the Sulphide Treatment Plant (STP), Tailings Treatment Plant (TTP) commissioned in 1988, Oxide Treatment Plant (OTP), Pompora Treatment Plant (PTP) commissioned in 1947, and the Heap Leach Plant (HLP) commissioned in 1990. Liquid effluent from STP which includes precipitated arsenic as ferric arsenate, sulphur as calcium sulphate, metals as insoluble hydroxides and flotation tails CIL residue from the BIOX leach process is pumped to the Sansu Tailings Dam (STD). The TTP tailings network of AGA, include the Pompora Tailings Dam, Kokoteasua East Dam and the Sansu Tailings Dam. Seepages from finger drains and run-offs from the Pompora Dam area flow into coffer dams, whereas decant water from the Kokoteasua East Dam flows into the Pompora valley. Decant 
from STD reports to a holding pond and is subsequently discharged into the Nyam River. Liquid effluent from the OTP is mainly from CIL residue circuit which is discharged into the STD. Process plant water at the OTP is recycled through the STD. Liquid effluent from the PTP area which include rainfall runoffs, decant water from Kokoteasua East Tailings Dam, Pompora Dam, underground water from North Ramp Mine, excess water from the Pompora sump is discharged into the Kwabrafo stream. The HLP has been decommisioned. There are various pits and waste dumps scattered with most of them concentrated at the central portion of the study area. Most of these pits were backfilled with material that potentially contain gold and arsenic and are likely to release arsenic when rehabilitation delays or the rehabilitated area is further disturbed. Arsenic occurs as a major constituent in more than 200 minerals, including elemental arsenic, arsenides, sulphides, oxides, arsenates and arsenites [17]. Most are ore minerals or their alteration products. However, these minerals are relatively rare in the natural environment $[11,17]$. The greatest concentrations of these minerals occur in mineralised areas and are found in close association with the transition metals as well as $\mathrm{Cd}, \mathrm{Pb}$, $\mathrm{Ag}, \mathrm{Au}, \mathrm{Sb}, \mathrm{P}, \mathrm{W}$ and Mo $[6,13,17]$. Arsenic is found primarily in the earth's crust with natural concentrations ranging between
0.1 to $40.0 \mathrm{mg} / \mathrm{kg}$ and average concentrations from 1.5 to 5.0 $\mathrm{mg} / \mathrm{kg}$ and is released naturally through volcanic, forest fires and geothermal, activities $[14,20]$. It is also found naturally in rocks, soils, sediments, water and biota around the surface of the earth [12]. Arsenic is often associated with iron and manganese in some sedimentary and igneous rocks $[12,18,19]$. Relevant and common arsenic containing minerals are arsenopyrite (FeAsS), realgar (AsS), and orpiment $\left(\mathrm{As}_{2} \mathrm{~S}_{3}\right)$. In the Obuasi Municipality, arsenic has been found to be associated with Ferrisymplesite $\left(\mathrm{Fe}_{3}\left(\mathrm{AsO}_{4}\right)_{2} \cdot 6 \mathrm{H}_{2} \mathrm{O}\right)$, Symplesite $\left(\mathrm{Fe}_{3}\left(\mathrm{AsO}_{4}\right)_{2} \cdot 8 \mathrm{H}_{2} \mathrm{O}\right)$, Liskerdite $(\mathrm{AlFe})_{3} \mathrm{AsO}_{4}(\mathrm{OH})_{6} \cdot 5 \mathrm{H}_{2} \mathrm{O}$ and Arseniosiderite $\left(\mathrm{Ca}_{3} \mathrm{Fe}_{4}(\mathrm{AsO} 4)_{3}(\mathrm{OH})_{8}{ }^{[4]}\right.$. Arsenic and trace metals may be released naturally to ground water or surface water through weathering, erosion and dissolution. Release of arsenic into the environment often results in significant environmental consequences $[7,9,10,11]$ as it is released along with other toxic metals. Table 1 shows a list of common minerals that contain arsenic. Arsenic has been observed to be prevalent in the Obuasi Municipality $[1,4,15,17]$. Currently no pattern has been established as a relationship between arsenate and trace metals in surface or groundwater of the Obuasi Municipality. This study seeks to identify any available pattern for management decisions.



Figure 1. Geological Map of Obuasi Municipality (Source: Extracted from Geological Map of Ghana). 
Table 1. Common Minerals of Arsenic.

\begin{tabular}{ll}
\hline Name & Chemical Formula \\
\hline Arsenopyrite & $\mathrm{FeAsS}$ \\
Smalite & $\mathrm{CoAs}_{2}$ \\
Lollingite, & $\mathrm{FeAs}_{2}$ \\
Cobaltite & $\mathrm{CoAsS}_{\text {Orpiment }}$ \\
Gersdorffite & $\mathrm{As}_{2} \mathrm{~S}_{3}$ \\
Realgar & $\mathrm{NiAsS}$ \\
Tennantite & $\mathrm{As}_{4} \mathrm{~S}_{4}$ \\
Chloanthite & $4 \mathrm{Cu}_{2} \mathrm{SAs}_{2} \mathrm{SiS}_{3}$ \\
Proustite & $\mathrm{NiAs}_{2}$ \\
Niciolite & $3 \mathrm{Ag}_{2} \mathrm{SAs}_{2} \mathrm{~S}_{3}$ \\
Enargite & $\mathrm{NiAs}$ \\
\hline
\end{tabular}

[Source: Ferguson, 1990]

\section{Materials and Methods}

Water Sampling: In total, 230 surface water samples were collected from 25 river sampling points, 160 stream sampling points and 45 ponds. As well, 142 ground water samples were collected from 108 community boreholes, 18 monitoring boreholes, 11 hand-dug wells and 5 mechanised borehole systems in 96 settlements in the study area (Figure 2).

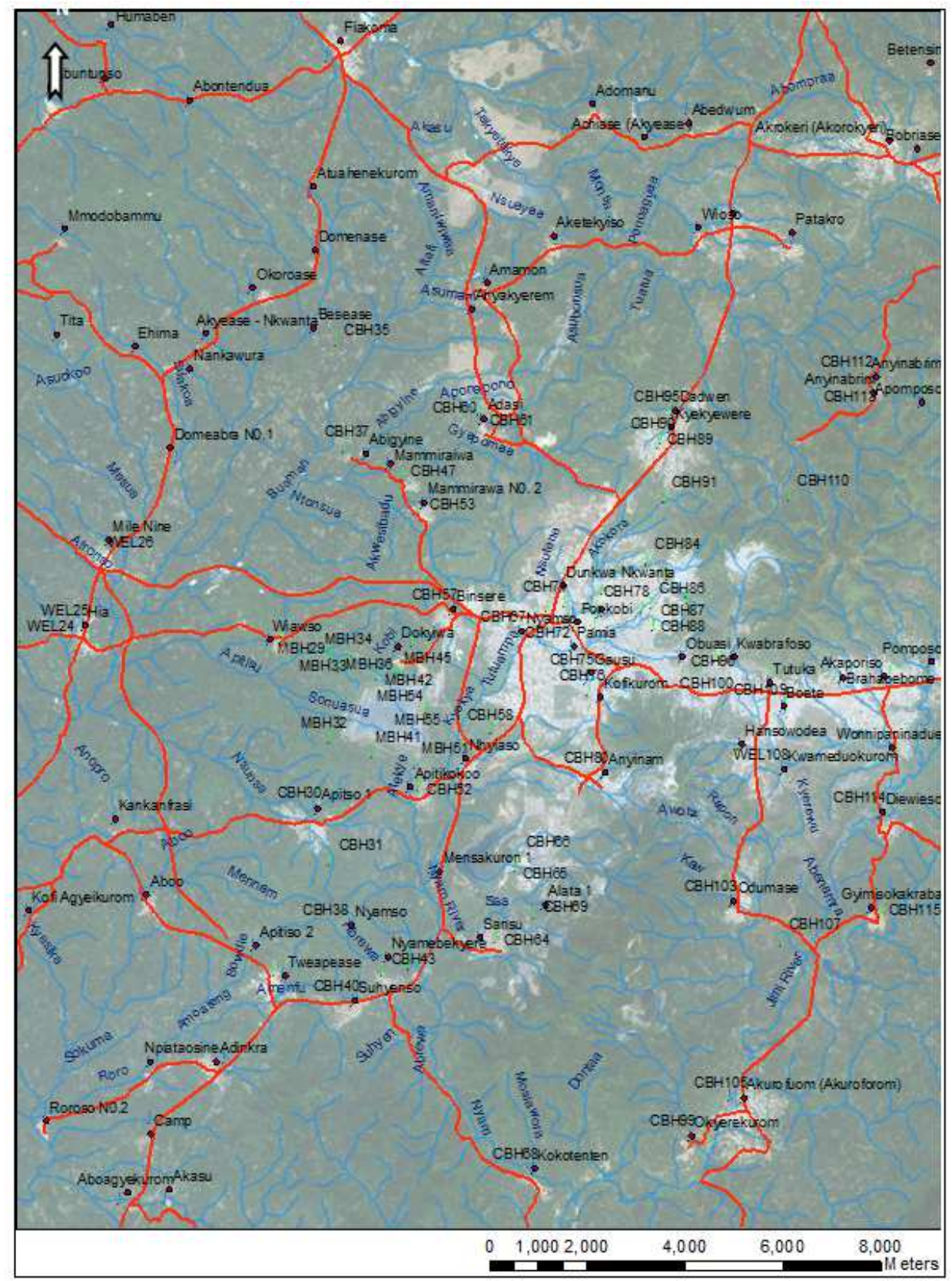

Figure 2. Surface and Groudwater Sampling Points on Surface Water Map Superimposed on Rapid Eye Satellite Image of Obuasi Municipality. 
The groundwater and surface water samples were transported in ice chests with ice packs stored at approximately $4^{\circ} \mathrm{C}$ and analyzed at the Societe General Surveillance (SGS) MASLAB Environmental Laboratory in Ghana. Samples which were analysed for heavy and base metals were preserved with $5 \mathrm{ml}$ of ultrapure grade concentrated $\mathrm{HCl}$ acid in the laboratory. All samples collected for arsenic analysis were preserved using ultrapure grade $\mathrm{HCl}$ acid. Approximately $90 \mu \mathrm{l}$ of acid was added per $60 \mathrm{ml}$ sample that resulted in a $\mathrm{pH}$ slightly below 2.0. A Varian SpectrAA 55 atomic absorption spectrometer with a Varian Vapor Generating Accessory (VGA) 77 was used for analyzing the samples for dissolved arsenic. The instrument was calibrated using freshly prepared arsenic standards $(2,5,10,20$, $30 \mu \mathrm{g} / \mathrm{L}$ ) with a $0.1 \% \mathrm{HCl}$ acid concentration. Agilent Spectra AA55 Atomic Absorption Spectrophotometer (AAS) was used to analyse metals whiles the Agilent VGA 77 Vapour Generating Accessories along with the Agilent Spectra AA 55 was used for analysis of total As. The Agilent VGA 77 unit was operated with 99.99\% Argon in a dust-free environment at the required pressure range of 300 to $400 \mathrm{kPa}$ (43 to $57 \mathrm{psi}$ ) and normal flow rate of $100 \mathrm{~mL} /$ minute. For quality assessment/quality control standards including NIST Standard Reference materials and a dionised water (as a reference sample blank) were analyzed together with the water samples. Data quality was assessed using charge balance calculations, replicate samples and sample blanks. Charge balance errors are typically $<5 \%$. Replicate arsenic analysis samples and standards showed a precision within $5 \%$. Blank assays were found to be negligible. The limit of detection for $\mathrm{As}(\mathrm{III})$ and total arsenic with the VGA/AAS technique is $0.001 \mathrm{mg} / \mathrm{l}$ with an error of $\pm 70 \%$ at the $95 \%$ confidence interval. Concentrations between 0.001 and $0.010 \mathrm{mg} / \mathrm{l}$ have an error of \pm $25 \%$ at the $95 \%$ confidence interval. Concentrations between 0.010 and $0.050 \mathrm{mg} / \mathrm{l}$ have an error of $\pm 7 \%$ at the $95 \%$ confidence interval, and concentrations greater than $0.050 \mathrm{mg} / \mathrm{l}$ have an error of $\pm 3 \%$ at the $95 \%$ confidence interval. Inorganic $\mathrm{As}(\mathrm{V})$ was determined by calculating the difference between total inorganic As and As(III). This assumes there is no organic arsenic present in the water.

Table 2. Arsenic Guiding Standard for Ghana Groundwater and Surface Water.

\begin{tabular}{lll}
\hline ARSENIC GUIDING STANDARDS & & \\
\hline Guiding Standards & Risk Class & Arsenic Conc. (mg/l) \\
Greater than EPA Akoben Effluent Limit & Very High & $>0.100$ \\
Greater than ECLimit to EPA Akoben Limit & High & $>0.050-0.100$ \\
Greater than WHO/GWC Limit to EC Limit & Medium & $>0.010-0.050$ \\
Greater than Detection Limit to WHO Limit & Low & $>0.001-0.010$ \\
Less than or Equal to Detection Limit & Very Low & $\leq 0.001$ \\
EPA - Ghana Environmental Protection Agency & & \\
EC - European Commission & & \\
WHO - World Health Organisation & & \\
GWC - Ghana Water Company & & \\
\hline
\end{tabular}

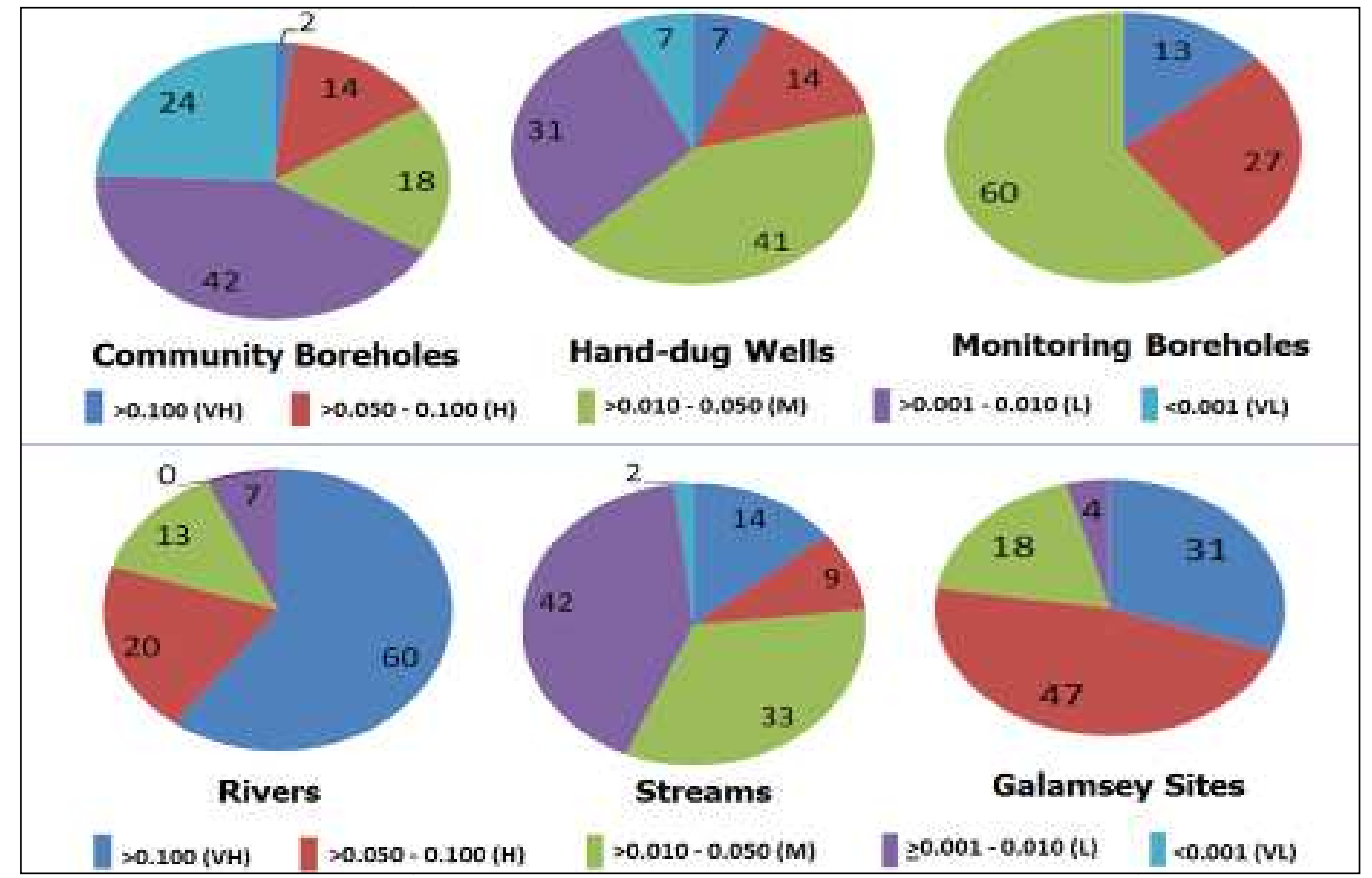

Figure 3. Percentage Arsenate in Surface Water and Groundwater of Obuasi Municipality (As concentrations in mg/l). 


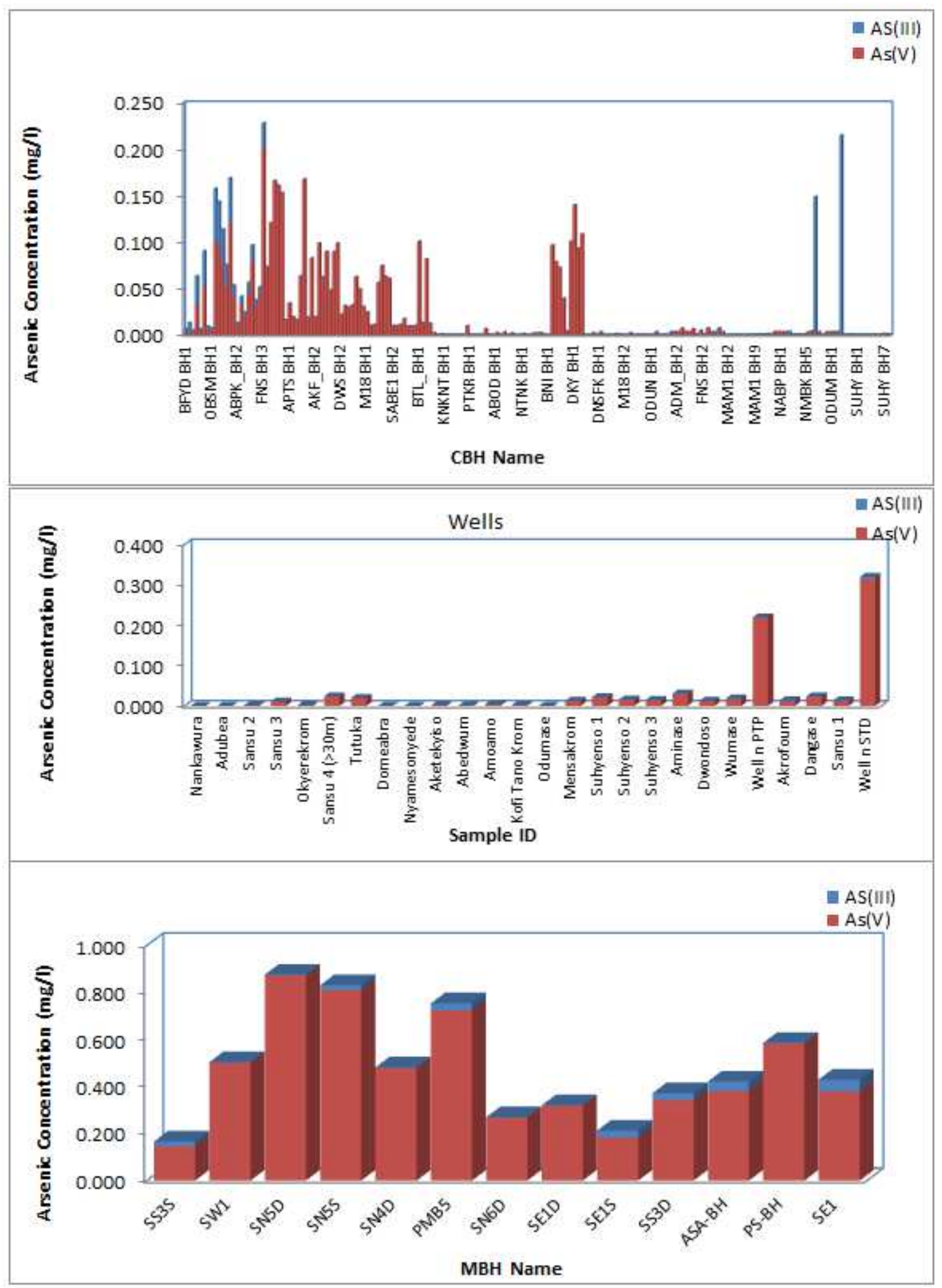




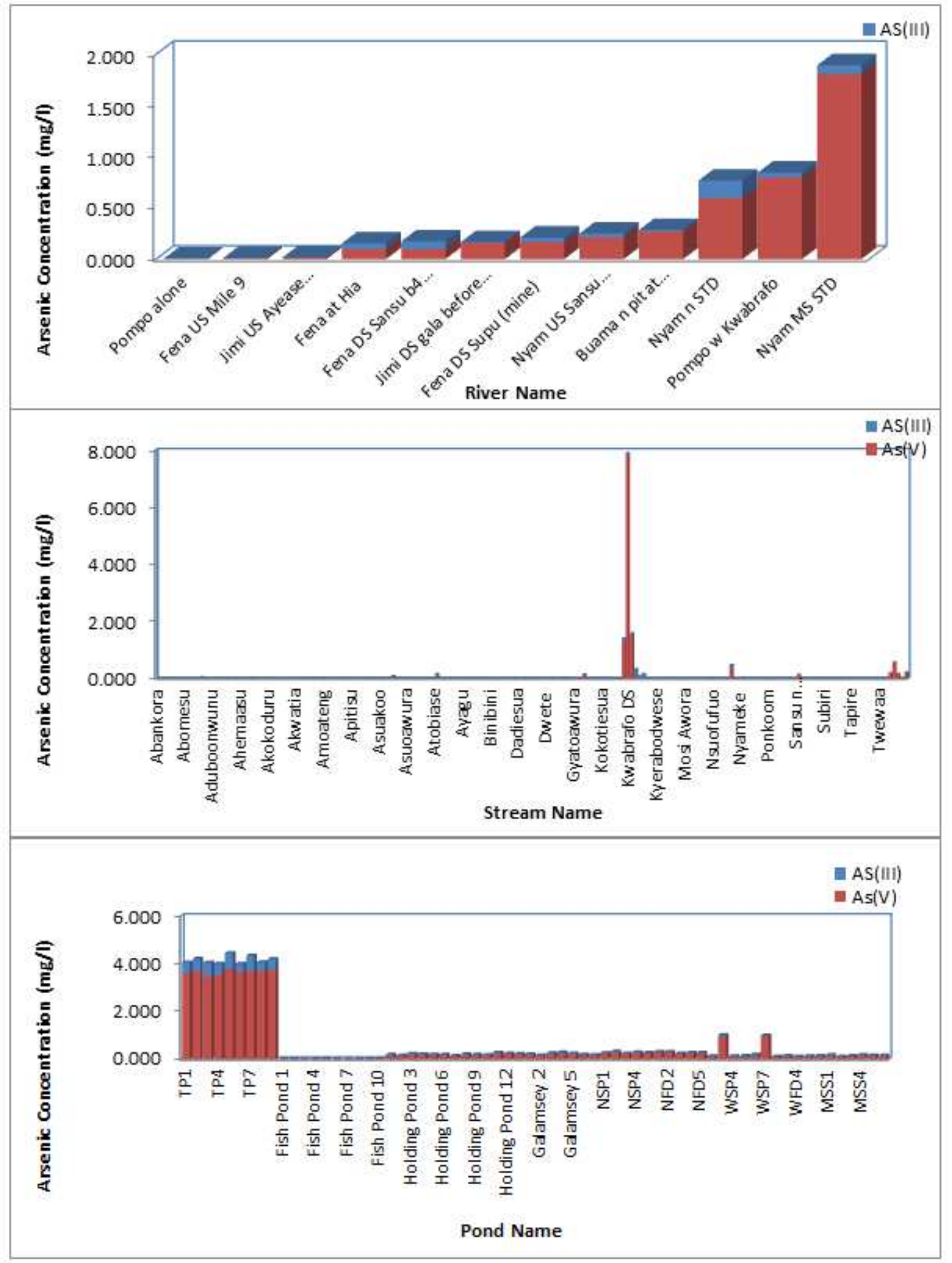

Figure 4. Arsenate Distributions in Surface Water and Groundwater of Obuasi Municipality.

\section{Results and Discussion}

\subsection{Statistical Summary of Arsenic in Surface and Groundwater of Obuasi Municipality}

Percentage distribution of arsenate in the study area is shown in Figure 3 whiles arsenate content of surface and groundwater sites is shown in Figure 4. Generally, except for monitoring boreholes which are not used for domestic activity, groundwater $(\mathrm{CBH}, 66 \%$; Wells, 40\%; $\mathrm{MBH}, 0 \%)$ has relatively higher percentage of sampling sites than surface water (streams, $44 \%$; rivers, $7 \%$; and ponds $4 \%$ ) with arsenate concentration below the WHO standard of $0.010 \mathrm{mg} / \mathrm{l}$ ) in the study area. It is also observed that except for monitoring 
boreholes, groundwater (CBH, 98\%; Wells, 93\%; MBH, 87\%) has relatively higher percentage of sampling sites than surface water (streams, $86 \%$; rivers, $40 \%$; and ponds, 69\%) with arsenate concentration below the EU standard of $0.050 \mathrm{mg} / \mathrm{l}$ ) in the study area. Generally, except for monitoring boreholes, groundwater (CBH, 84\%; Wells, 81\%; and $\mathrm{MBH}, 60 \%)$ has relatively higher percentage of sampling sites than surface water (streams, $77 \%$; rivers, $20 \%$; and ponds, $22 \%$ ) with arsenate concentration below the EU standard of $0.050 \mathrm{mg} / \mathrm{l}$ in the study area.

\subsection{Influence of Trace Elements on Arsenate Concentration}

To evaluate the distribution of arsenic in the studied water, concentrations of various trace elements including $\mathrm{Al}, \mathrm{Ag}, \mathrm{B}$, $\mathrm{Ba}, \mathrm{Be}, \mathrm{Ca}, \mathrm{Ce}, \mathrm{Co}, \mathrm{Cr}, \mathrm{Cs}, \mathrm{Cu}, \mathrm{Eu}, \mathrm{Dy}, \mathrm{Fe}, \mathrm{Ga}, \mathrm{Gd}, \mathrm{Ge}, \mathrm{Ho}, \mathrm{K}$, Li, Lu, Mg, Mn, Mo, Na, Nd, Ni, Pb, Pr, Rb, Sb, Sm, Sr, Tb, Tl, $\mathrm{Tm}, \mathrm{U}, \mathrm{Y}, \mathrm{Tb}, \mathrm{Zn}$ and $\mathrm{Zr}$ were determined in selected water samples and statistical analysis performed on the dataset to identify trend in the analytical results. Generally, trace elements such as B, Be, Ce, Co, Cr, Cs, Eu, Dy, Ga, Gd, Ge, Ho, Lu, Mo, Nd, Ni, Pr, Pb, Rb, Sb, Sm, Sr, Tb, Tl, Tm, U, Y, $\mathrm{Tb}$ and $\mathrm{Zr}$ were not detected in statistically significant quantities for analysis. However, trace elements such as Al, Ba, $\mathrm{Cu}, \mathrm{Fe}, \mathrm{Li}, \mathrm{Mn}, \mathrm{Sr}$, and $\mathrm{Zn}$ showed varying trends and were used in the analysis to determine their relationship with total arsenic or any of its species. Arsenic appears to show some relationship with $\mathrm{Sr}$ and to a lesser extent $\mathrm{Ba}$ in both surface and groundwater. The associations between $\mathrm{As}$ and $\mathrm{Sr}$ in groundwaters of the study area supports the fact that arsenic has been derived from arsenic bearing ore minerals.

\subsection{Influence of Trace Elements on Arsenate Concentration in $\mathrm{CBH}$}

Three classes of $\mathrm{CBH}$ were identified per their trace element relationship with $\mathrm{As}(\mathrm{V})$ in the study area as follows (Figure 5):

1. $\mathrm{CBH}$ with very low to medium arsenate $(0.001 \mathrm{mg} / \mathrm{l}$ to $0.010 \mathrm{mg} / \mathrm{l}$ ) showed positive linear correlation with $\mathrm{Fe}$, $\mathrm{Sr}, \mathrm{Li}, \mathrm{Mn}, \mathrm{Zn}$ whilst, $\mathrm{Ba}, \mathrm{Cu}$ showed negative linear correlation; and

2. $\mathrm{CBH}$ with medium to high arsenate $(0.010 \mathrm{mg} / 1$ to 0.100 $\mathrm{mg} / \mathrm{l})$ showed positive linear correlation with $\mathrm{Sr}$ and $\mathrm{Al}$ whilst, $\mathrm{Fe}, \mathrm{Ba}, \mathrm{Cu}, \mathrm{Zn}$, Li showed negative linear correlation.

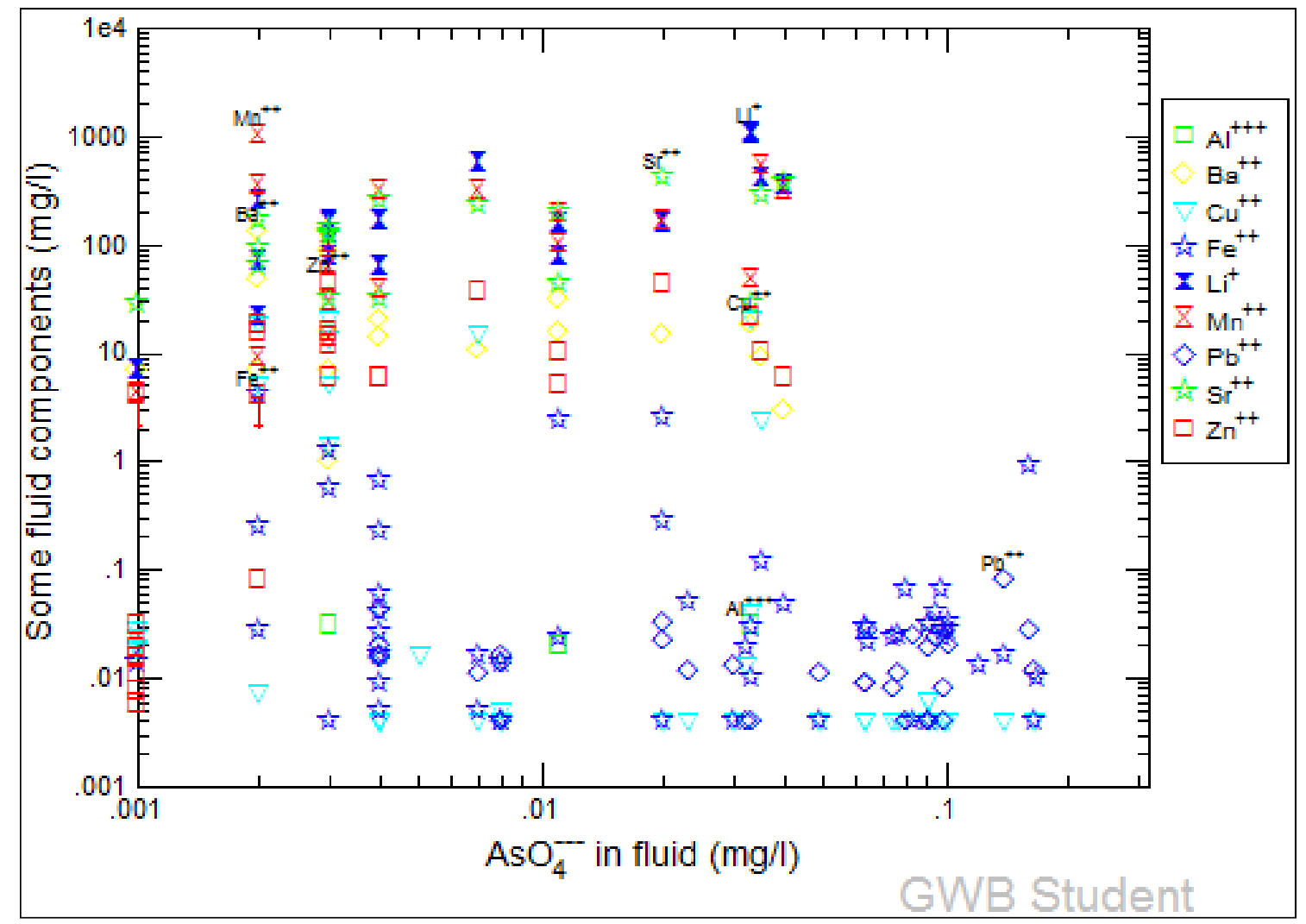

Figure 5. Log-Log Relationship between $A s(V)$ and Trace Elements in CBH.

\subsection{Influence of Trace Elements on Arsenate Concentration in Wells}

Two classes of wells were identified per their trace element relationship with As(V) in the study area as follows (Figure 6):

1. Wells with very low to medium arsenate $(<0.010 \mathrm{mg} / \mathrm{l})$ showing negative correlation between $\mathrm{As}(\mathrm{V})$ and $\mathrm{Fe}, \mathrm{Zn}, \mathrm{Al}$ and positive correlation for $\mathrm{Sr}, \mathrm{Li}, \mathrm{Ba}$, and $\mathrm{Mn}$; and

2. Wells with medium to very high arsenate $(>0.010 \mathrm{mg} / \mathrm{l})$ showing negative correlation between $\mathrm{As}(\mathrm{V})$ and $\mathrm{Cu}, \mathrm{Ni}, \mathrm{Sr}, \mathrm{Zn}, \mathrm{Mn}$ and positive correlation for $\mathrm{Fe}, \mathrm{Ba}, \mathrm{Al}$. 


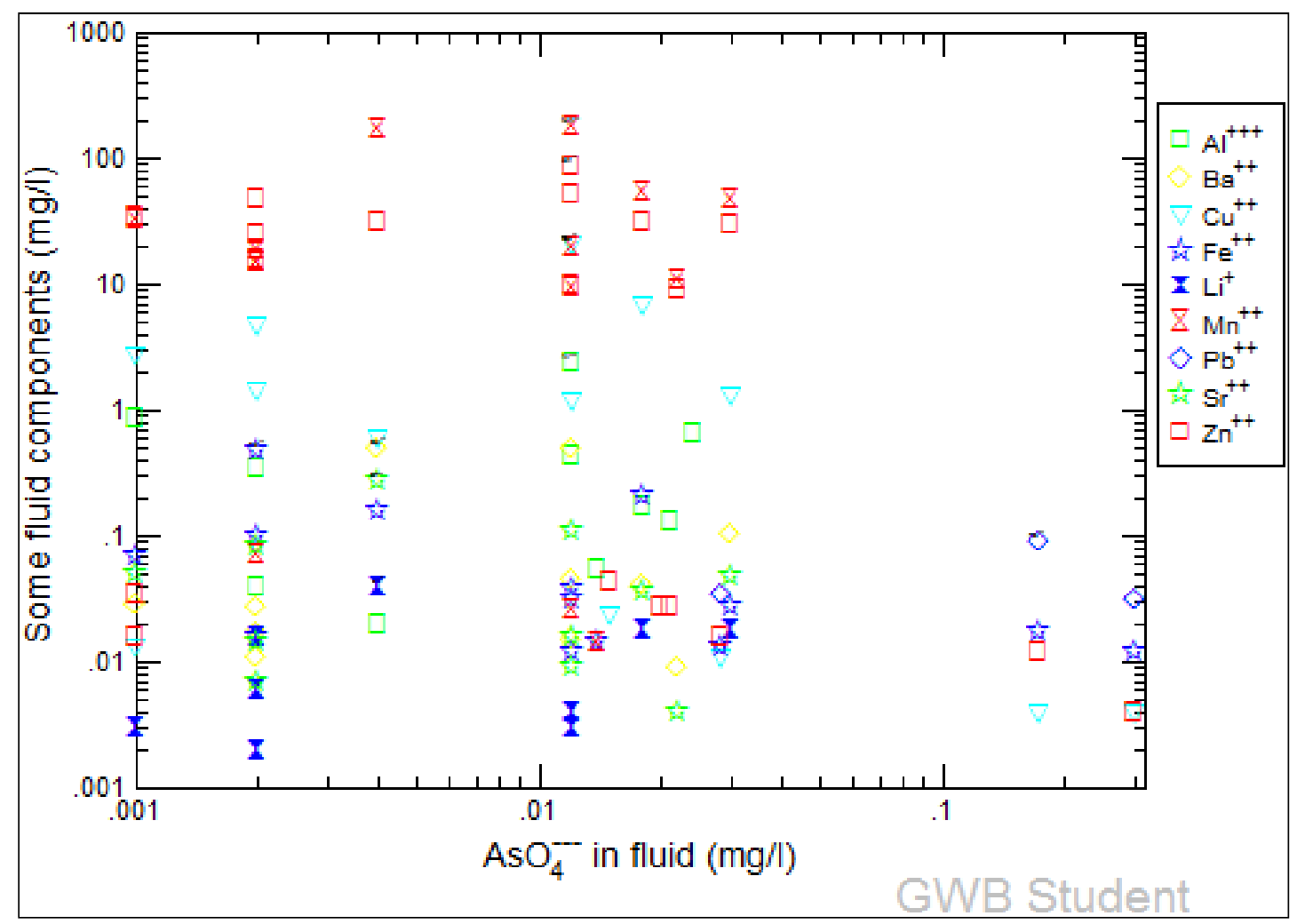

Figure 6. Log-Log Relationship between As(V) and Trace Elements in Wells.

\subsection{Influence of Trace Elements on Arsenate Concentration in MBH}

Arsenate concentration in MBH showed positive correlation with $\mathrm{Cu}$ and negative correlation with $\mathrm{Fe}, \mathrm{Zn}$ and Mn (Figure 7).

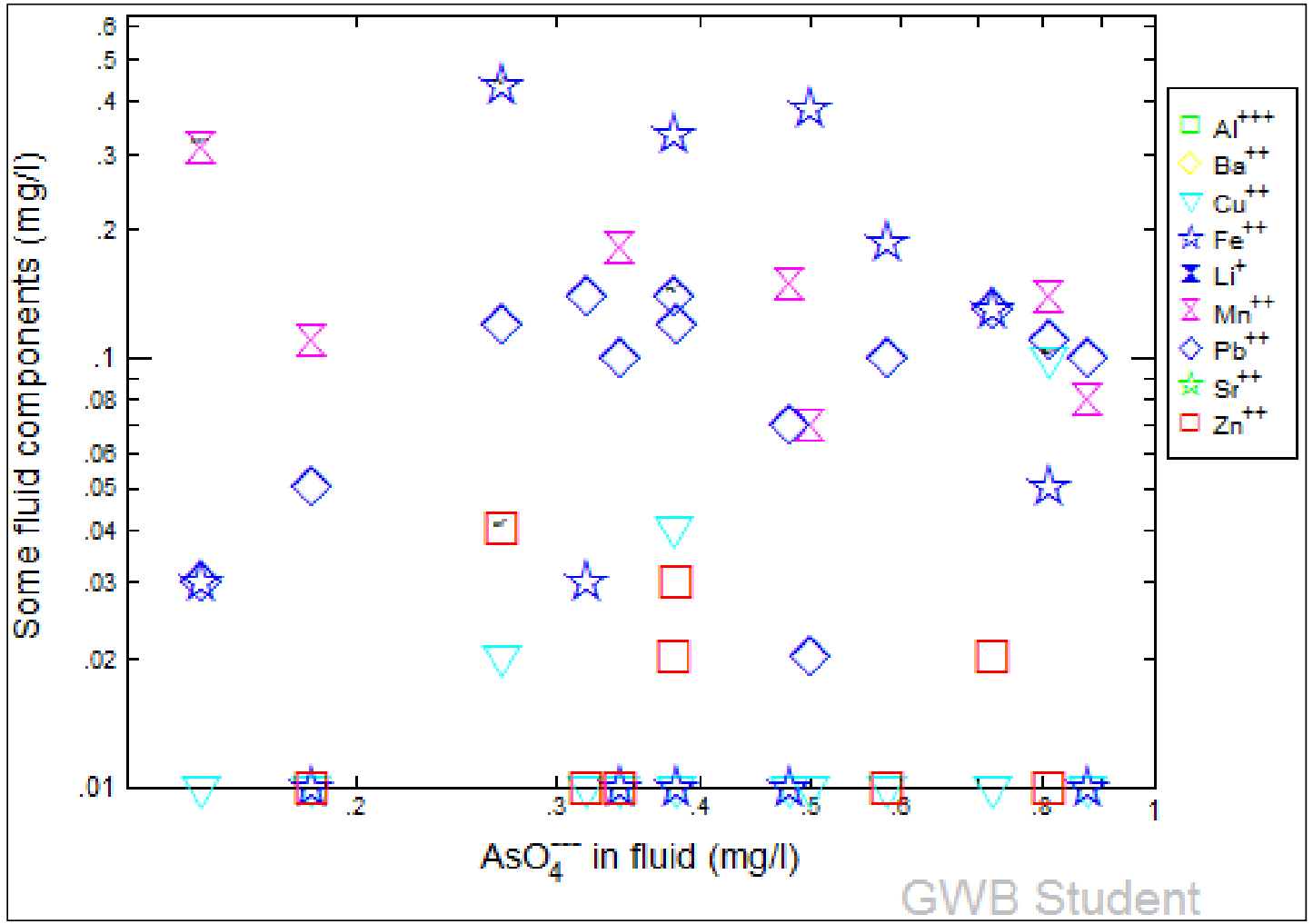

Figure 7. Log-Log Relationship between As(V) and Trace Elements in MBH. 


\subsection{Influence of Trace Elements on Arsenate Concentration in Streams}

Three classes of streams were identified per their trace element relationship with $\mathrm{As}(\mathrm{V})$ in the study area as follows (Figure 8):

1. Very Low to low arsenate $(0.001 \mathrm{mg} / \mathrm{l}$ to $0.010 \mathrm{mg} / \mathrm{l})$ : Negative linear correlation between $\mathrm{Mn}, \mathrm{Cu}$ and positive linear correlation for $\mathrm{Fe}, \mathrm{Al}, \mathrm{Ba}, \mathrm{Sr}, \mathrm{Li}$ and $\mathrm{Zn}$; and

2. Medium arsenate $(0.010 \mathrm{mg} / \mathrm{l}$ to $>0.050 \mathrm{mg} / \mathrm{l})$ : Negative linear correlation between $\mathrm{Mn}, \mathrm{Cu}$ and positive linear correlation for $\mathrm{Sr}, \mathrm{Li}, \mathrm{Fe}, \mathrm{Zn}, \mathrm{Ba}$, and $\mathrm{Al}$.

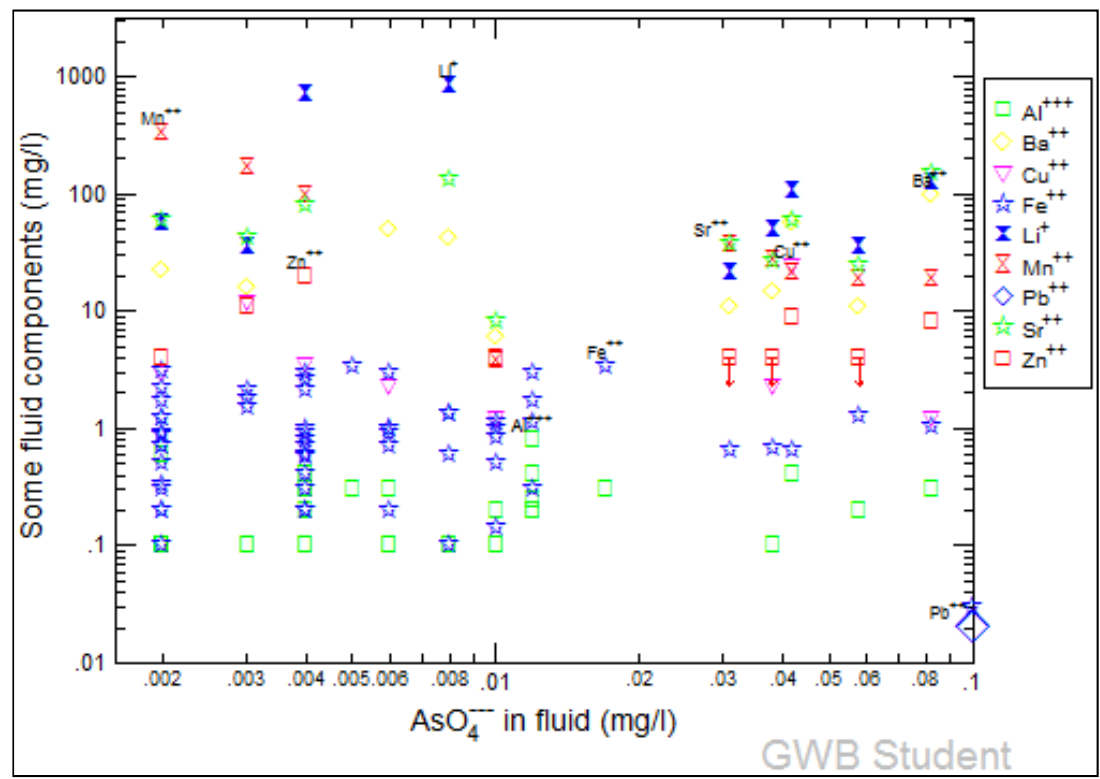

Figure 8. Log-Log Relationship between $A s(V)$ and Trace Elements in Streams.

\subsection{Influence of Trace Elements on Arsenate Concentration in Rivers}

Rivers were identified per their trace element relationship with $\mathrm{As}(\mathrm{V})$ in the study area as follows (Figure 9):

1. Very low to high arsenate $(<0.100 \mathrm{mg} / \mathrm{l})$ : negative linear correlation with $\mathrm{Sr}$ and $\mathrm{Cu}$; and positive linear correlation with $\mathrm{Sr}$, $\mathrm{Mn}, \mathrm{Li}, \mathrm{Al}, \mathrm{Fe}, \mathrm{Zn}$ and Ba.

2. Very high arsenate $(>0.100 \mathrm{mg} / \mathrm{l})$ negative linear correlation with $\mathrm{Zn}, \mathrm{Fe}$ and $\mathrm{Mn}$; and positive linear correlation with $\mathrm{Al}, \mathrm{Cu}$, $\mathrm{Li}, \mathrm{Sr}$ and $\mathrm{Ba}$

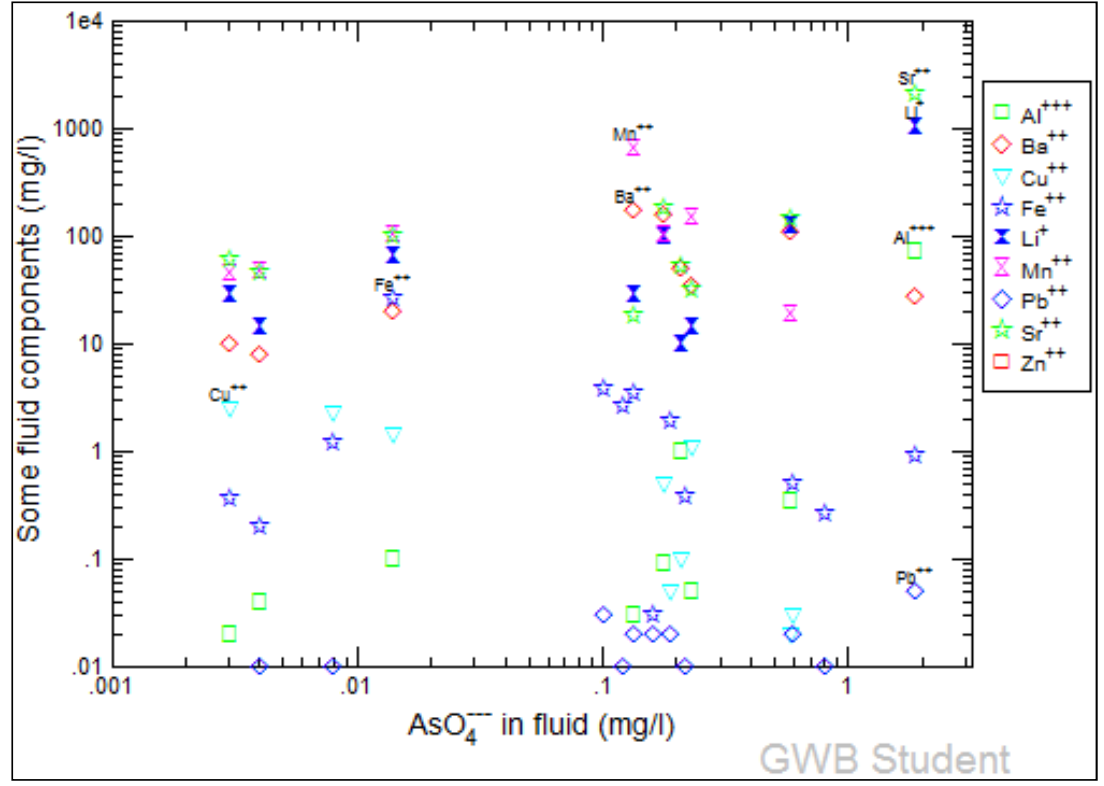

Figure 9. Log-Log Relationship between As(V) and Trace Elements in Rivers. 


\subsection{Influence of Trace Elements on Arsenate Concentration in Ponds}

1. No clear trend between $A s(V)$ and the trace elements was identified. However, three main clusters were observed on the Semi-log plot of $\mathrm{As}(\mathrm{V})$ vs. $\log$ of selected trace elements (Figure 10).

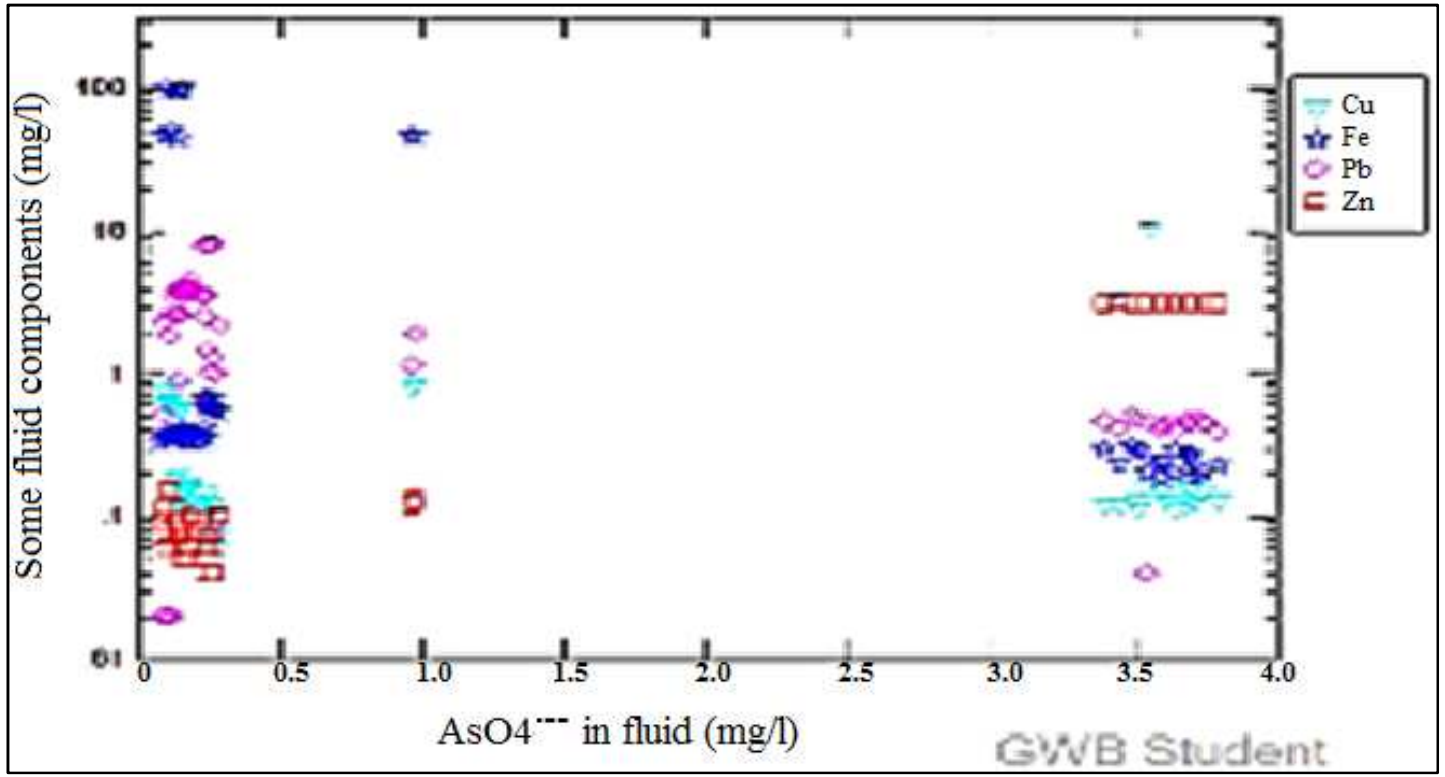

Figure 10. Semi-Log Relationship between As(V) and Trace Elements in Ponds.

\subsection{Summary of Trace Elements and Arsenate Concentration in Surface and Groundwater}

The relationship between arsenate and trace elements in groundwater of the study area can be summarized as follows:

$C B H$ : It was observed that generally for $\mathrm{CBH}$ at low to medium $\mathrm{As}(\mathrm{V})$ concentration, as $\mathrm{As}(\mathrm{V})$ increase $\mathrm{Fe}, \mathrm{Sr}, \mathrm{Li}$, $\mathrm{Mn}, \mathrm{Al}$ and $\mathrm{Zn}$ increase. The positive trend changes at medium to high $\mathrm{As}(\mathrm{V})$ concentration when $\mathrm{Fe}, \mathrm{Mn}$ and $\mathrm{Zn}$ begin to decrease whilst $\mathrm{Sr}, \mathrm{Li}$, and $\mathrm{Al}$ continue to increase with arsenate increase. $\mathrm{Ba}$ and $\mathrm{Cu}$ however consistently decrease with arsenate increase.

Wells: Interestingly for wells at low to medium $\mathrm{As}(\mathrm{V}), \mathrm{Sr}$, $\mathrm{Li}, \mathrm{Mn}, \mathrm{Ba}$ begin to increase whilst $\mathrm{Fe}, \mathrm{Al}$ and $\mathrm{Zn}$, begin to decrease. As arsenate concentration increases from medium to very high, $\mathrm{Fe}$ and $\mathrm{Al}$ begin to increase and $\mathrm{Cu}, \mathrm{Li}, \mathrm{Sr}, \mathrm{Zn}, \mathrm{Mn}$ begin to decrease. Ba however is consistently increasing. The following is a breakdown of the relationship between the individual trace elements and $\mathrm{As}(\mathrm{V})$ concentration in groundwater:

1. $\mathrm{Cu}$ is constantly reducing in groundwater with increasing $\mathrm{As}(\mathrm{V})$;

2. $\mathrm{Li}$ and $\mathrm{Sr}$ are constantly increasing in wells and constantly decreasing in $\mathrm{CBH}$ whilst $\mathrm{Ba}$ and $\mathrm{Li}$ are constantly increasing in $\mathrm{CBH}$ and constantly decreasing in wells;

3. At low arsenate: $\mathrm{Fe}$ increase in $\mathrm{CBH}$ and decrease in wells, but at high $\mathrm{As}(\mathrm{V}) \mathrm{Fe}$ decrease in $\mathrm{CBH}$ and increase in wells;

4. At low $\mathrm{As}(\mathrm{V})$ : $\mathrm{Al}$ decrease in $\mathrm{CBH}$ and wells, but at high $\mathrm{As}(\mathrm{V}), \mathrm{Al}$ increase in $\mathrm{CBH}$ and wells; and

5. At low $\mathrm{As}(\mathrm{V}): \mathrm{Mn}, \mathrm{Zn}, \mathrm{Li}$ increase in $\mathrm{CBH}$ and wells, but at high $\mathrm{As}(\mathrm{V}), \mathrm{Mn}, \mathrm{Zn}, \mathrm{Li}$ decrease in $\mathrm{CBH}$ and wells.

Figure 11 presents patterns for $\mathrm{As}(\mathrm{V})$ and trace elements relationship in wells and $\mathrm{CBHs}$ for the study area.

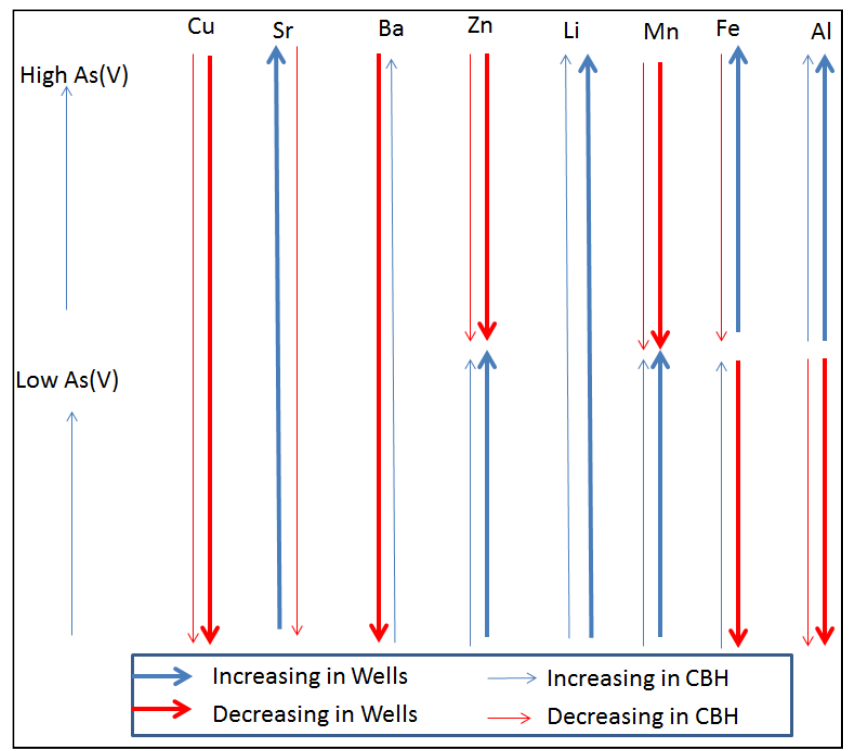

Figure 11. Patterns of Arsenate and Trace Elements Relationships in Wells and $\mathrm{CBH}$.

The generally high concentration of $\mathrm{Mn}, \mathrm{Cu}, \mathrm{Li}, \mathrm{Sr}, \mathrm{Ba}, \mathrm{Zn}$, $\mathrm{Fe}$ and $\mathrm{Al}$ in wells and boreholes suggests they are products of dissolution of host minerals occurring together. The relatively low $\mathrm{pH}$ of the water and concentration of these trace elements reflect the elements' abundance in the geological units being drained. It can also be observed that as $\mathrm{Sr}$ and $\mathrm{Li}$ are being leached from the host rock in wells at all concentrations, the 
process is reversed with the removal of $\mathrm{Ba}$, and $\mathrm{Cu}$ from solution. Likewise, $\mathrm{Zn}$ and $\mathrm{Mn}$ are leached into solution at low arsenate concentration with the removal of $\mathrm{Fe}$ and $\mathrm{Al}$. The process is reversed at high arsenate where $\mathrm{Zn}$ and $\mathrm{Mn}$ are removed, whilst $\mathrm{Fe}$ and $\mathrm{Al}$ are leached back into solution. Iron (Fe) and $\mathrm{Mn}$ may be released microbiologically and sometimes concurrently by the reductive dissolution of their metal oxides. At the circum-neutral $\mathrm{pH}$ of the study area (low arsenate), $\mathrm{Mn}$ is much more slowly oxidized than $\mathrm{Fe}$ and explains the low $\mathrm{Fe}$ and high $\mathrm{Mn}$ content of the groundwater. As the redox potential of the groundwater is lowered oxygen and nitrate will be reduced followed by $\mathrm{Mn}, \mathrm{Fe}$ and $\mathrm{SO}_{4}{ }^{2-}$ at high arsenate concentrations. Repeated redox cycles can increase the concentration of secondary oxides of Fe, Mn and $\mathrm{Al}$ in the sediments of the groundwater which can be demobilized later upon agitation, microbial action or temperature changes. This suggest two arsenic mobilization processes are taking place in wells where in one instance there is infiltration from an external source (probably close arsenic storage structures) whilst the second process is leaching of the mineralized host rock. The processes taking place in $\mathrm{CBH}$ are similar to that in wells, except that in $\mathrm{CBH}, \mathrm{Zn}, \mathrm{Mn}$ and $\mathrm{Fe}$ are leached into solution at low arsenate concentration with a concurrent removal of only Al. The process is also reversed at high arsenate where $\mathrm{Zn}, \mathrm{Mn}$ and Fe are removed, whilst $\mathrm{Al}$ is leached back into solution. It would therefore be misleading to attempt to predict the concentration of arsenic in groundwater on the basis of their Fe contents alone. However, it can be noted that wells (not $\mathrm{CBH}$ ) with low Fe will tend to have low arsenate concentration. All others cannot be clearly predicted. Even though it is not sufficient to predict the actual concentration of arsenic from the $\mathrm{Fe}$ concentration of the groundwater, the presence of high $\mathrm{Fe}$ in any well or borehole is a definite indication of high arsenic in groundwater. The relationship between arsenate and trace elements in surface water of the study area can be summarized as follows:

Streams: At very low to low increasing arsenate, $\mathrm{Fe}, \mathrm{Ba}, \mathrm{Sr}$, $\mathrm{Li}, \mathrm{Al}, \mathrm{Zn}$ increase and $\mathrm{Mn}, \mathrm{Cu}$ decrease. As arsenate increase to medium $\mathrm{Fe}, \mathrm{Ba}, \mathrm{Sr}, \mathrm{Li}, \mathrm{Al}, \mathrm{Zn}$ continue to increase whilst $\mathrm{Cu}$ and $\mathrm{Mn}$ consistently decrease.

Rivers: At very low to high increasing $\mathrm{As}(\mathrm{V}), \mathrm{Fe}, \mathrm{Al}, \mathrm{Zn}$, $\mathrm{Mn}, \mathrm{Ba}, \mathrm{Sr}$, and $\mathrm{Li}$ begin to increase and $\mathrm{Cu}$ begin to decrease till very high arsenate when $\mathrm{Al}, \mathrm{Cu}, \mathrm{Li}, \mathrm{Sr}$ increases and $\mathrm{Ba}, \mathrm{Fe}$, $\mathrm{Mn}, \mathrm{Zn}$ begin to decrease. The following is a summary of the relationship between the individual trace elements and As(V) concentration in surface water:

1. $\mathrm{Sr}, \mathrm{Ba}, \mathrm{Li}$ and $\mathrm{Al}$ consistently increase in Streams and rivers;

2. Fe and $\mathrm{Zn}$ consistently increase in streams, but increase in rivers at low $\mathrm{As}(\mathrm{V})$ and decreases at very high $\mathrm{As}(\mathrm{V})$;

3. Mn consistently decrease in streams, but increase in rivers at low $\mathrm{As}(\mathrm{V})$ and decrease at very high $\mathrm{As}(\mathrm{V})$; and

4. $\mathrm{Cu}$ consistently decrease in rivers, but decrease in rivers at low $\mathrm{As}(\mathrm{V})$ and increase at very high $\mathrm{As}(\mathrm{V})$.

Figure 12 presents patterns for $\mathrm{As}(\mathrm{V})$ and trace elements relationship in surface water for the study area.

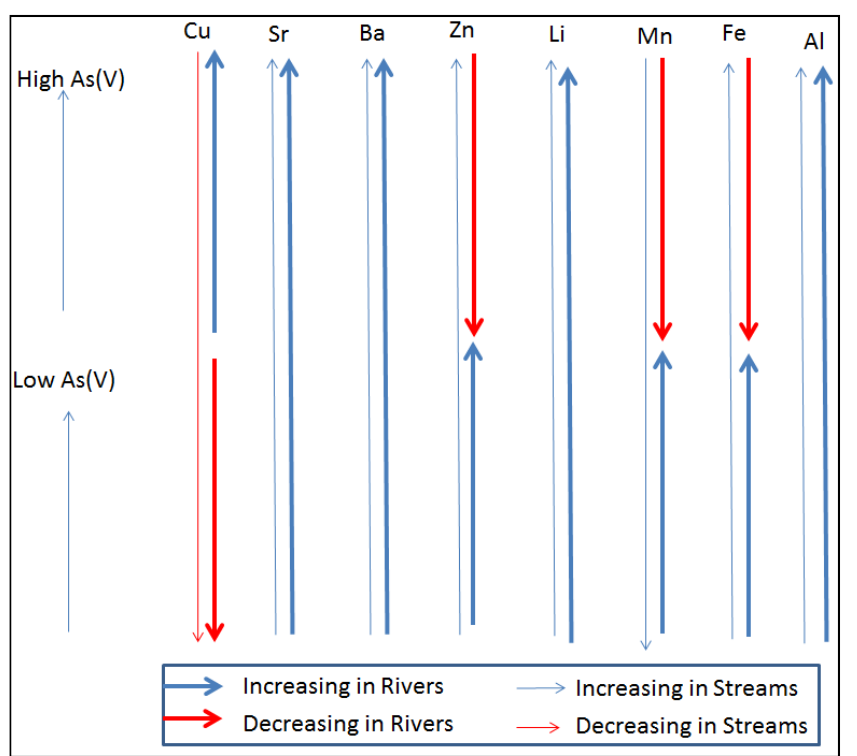

Figure 12. Patterns of Arsenate and Trace Elements Relationships in Streams and Rivers.

The positive correlation between arsenate and $\mathrm{Sr}, \mathrm{Ba}, \mathrm{Li}, \mathrm{Al}$ at all concentrations of arsenate suggest that arsenic and these trace elements are likely derived from leaching of the localized mineral ${ }^{[16]}$. Low $\mathrm{pH}$ and high concentrations of $\mathrm{Mn}$, $\mathrm{Zn}$ and $\mathrm{Fe}$ suggests oxidation of the host minerals is taking place in streams to oxidise pyrite and release $\mathrm{SO}_{4}{ }^{2-}$ and $\mathrm{Fe}$ into solution. The oxidation process is likely to mobilise arsenic into streams. The reverse process of reduction is taking place at high arsenate concentrations in rivers where pyrite is being formed with the cementation of zinc and formation of minerals of manganese. The relatively low $\mathrm{pH}$ and highly reduced rivers is likely to initiate reduction of $\mathrm{As}(\mathrm{V})$ and mobilise As(III) into rivers. Figure 13 shows the relationship between $\mathrm{As}(\mathrm{III})$ content and Eh with $\mathrm{pH}$ of rivers.

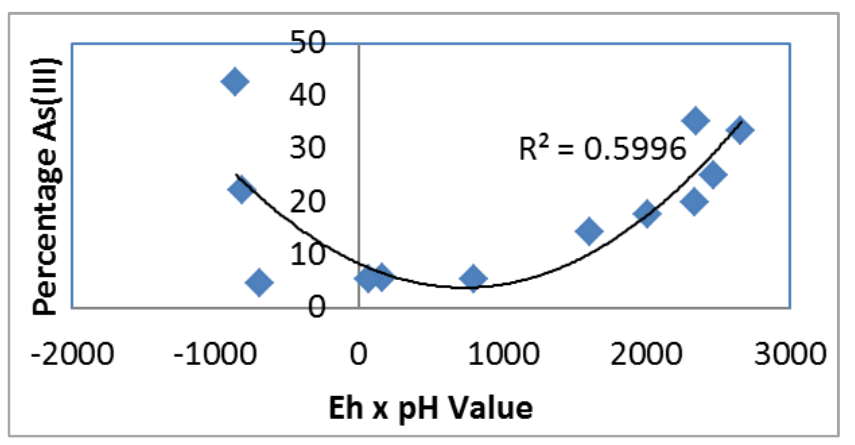

Figure 13. Relationships between Percentage As(III) and Eh x pH of Rivers.

\section{Conclusion}

The study has confirmed the distribution of arsenate and other trace metals in the Obuasi Municipality and identified patterns between some of the trace metals and arsenate concentration of surface water and groundwater in the study area. In particular metals such as $\mathrm{Cu}, \mathrm{Sr}, \mathrm{Ba}, \mathrm{Zn} \mathrm{Li}, \mathrm{Mn}, \mathrm{Fe}$ and $\mathrm{Al}$ have been found to have definite patterns with low or high levels of arsenate in the surface and groundwater of the study 
area. It is not advisable to attempt to predict the concentration of arsenic in groundwater on the basis of their Fe contents alone. However, it can be noted that wells (not community boreholes) with low $\mathrm{Fe}$ will tend to have low arsenate concentration. All others cannot be clearly predicted. Even though it is not sufficient to predict the actual concentration of arsenic from the Fe concentration of the groundwater, the presence of high $\mathrm{Fe}$ in any well or borehole is a definite indication of high arsenic in groundwater of Obuasi Municipality.

\section{References}

[1] Akabzaa, T.M., Banoeng-Yakubu, B., and Seyire, J.S. (2005). Heavy metal contamination in some mining communities within Jimi river basin in Ashanti Region. Journal of the Ghana Science Association, 7 (1).

[2] Amanor, J. A. and Gyapong, W. A. (1988). The Geology of Ashanti Goldfields. Report of the Ashanti Goldfields Corporation, Obuasi, Ghana.

[3] Amponsah-Tawiah, K., and Dartey-Baah, K. (2011). The Mining Industry in Ghana: A Blessing or a Curse, International Journal of Business and Social Science Vol. 2 No. 12; July 2011. 62p.

[4] Anon. (1998). Environmental Impact Assessment Report for Backfilling of Dokyiwa Pits, Obuasi, Ashanti Region, Ghana (Contract No C1419), Ashanti Goldfields Company Limited, Maisa Consul Ventures, UST, Kumasi, p.1-41.

[5] Bowell, R. J. (1993). Mineralogy and geochemistry of tropical rain forest soils: Ashanti, Ghana. Chem. Geol. 106, p.345-358.

[6] Clifford, D., Zhang, Z. (1994). Modifying ion exchange for combined removal of uranium and radium, Journal of the American Water Works Association, 86(4):pp. 214-227.

[7] Courtin-Nomade, A., Neel, C., Bril, H., and Davranche, M. (2002). Trapping and mobilisation of arsenic and lead in former mine tailings - Environmental conditions effects, Bull. Soc. Geol. Fr. 173, p.479-485.

[8] Ferguson, J. E., and Gavis, J. (1972). A review of the arsenic cycle in natural waters, Water Res 6:pp. 1259-1274.

[9] Foli, G., Apea, O. B., and Amedjoe, C. G. (2011). Pre-mining water quality prediction from non-weathered sulphide ores along the Ashanti metallogenic belt in Ghana using Acid-Base accounting procedure Am. J. Sci. Ind. Res., 2(5): pp.827-833.
[10] Irgolic, K. J. (1994). Determination of total arsenic and arsenic compounds in drinking water. In: Arsenic: Exposure and Health, Chappell, W. R., Abernathy, C. O. and Cothern, C. R. (eds.) Science and Technology Letters. Northwood, England, pp. 51 - 60.

[11] Jordan, T. E., Correll, D. L., and Weller, D. E. (1997). Effects of agriculture on discharges of nutrients from Coastal Plain watersheds of Chesapeake Bay, J. Environ. Qual., 26, pp. 836-848.

[12] Moreno-Jiménez, E., Clemente, R., Mestrot, A., Meharg, A. A. (2013). Arsenic and selenium mobilisation from organic matter treated mine spoil with and without inorganic fertilization, Environmental Pollution 173, pp.238-244.

[13] National Research Council (NRC). (1977). Arsenic: Medical and Biological Effects of Environmental Pollutions. National Academy of Sciences. Washington D.C., 332 p.

[14] Navarro Torres, V. F., Aduvire, O., Singh R. N. (2012). Assessment of natural attenuation of acid mine drainage pollutants in El Bierzo and Odiel basins: A case study, Journal of Mining \& Environment Vol.2, No.2, 2011, pp.78-85.

[15] Perrouty, S., Aillères, L., Jessell, M. W., Baratoux, L., Bourassa, Y., and Crawford, B. (2012). Revised Eburnean geodynamic evolution of the gold-rich southern Ashanti Belt, Ghana, with new field and geophysical evidence of pre-Tarkwaian deformations, Precambrian Research 204- 205 pp. 12- 39.

[16] Plumlee, G. S., Smith, K. S., Montour, M. R., Ficklin, W. H., and Mosier, E. L. (1999). Geologic controls on the composition of natural waters and mine waters draining diverse mineral deposits, in Plumlee, G. S., and Filipek, L. H., eds., The Environmental Geochemistry of Mineral Deposits Part B: Case Studies and Research Topics, Reviews in Econ. Geology, vol. 6B: Littleton, CO, Soc. Econ. Geologists, p.373-409.

[17] Smedley, P. L. (1996). Arsenic in rural groundwater in Ghana. J. Afr. Earth Sci. 22, pp. 459-470.

[18] Stollenwerk, K. G. (2003). Geochemical Processes Controlling Transport of Arsenic in Groundwater: A review of Adsorption. In Arsenic in Groundwater, Alan H. Welch \& Kenneth G. Stollenwerk Editors. Kluwert Academic Publishers, pp. 67-125.

[19] Yidana, S. M., Banoeng-Yakubo, B., and Sakyi P. A. (2012). Identifying key processes in the hydrochemistry of a basin through the combined use of factor and regression models, $J$. Earth Syst. Sci. 121, No. 2, April 2012, pp. 491-507.

[20] Zhang, Xuexia; et al. (2008). "Phylogenetic analysis and arsenate reduction effect of the arsenic-reducing bacteria enriched from contaminated soils at an abandoned smelter site". Journal of Environmental Sciences 20 (12). 